\title{
Antimicrobial activity of some cephalosporins with special reference to their effects on body weight and immune response to Newcastle disease vaccine in fayoumy chicks
}

\author{
I. A. Radwan ${ }^{1}$, Abeer M. $\operatorname{Radi}^{2}$ * \\ ${ }^{1}$ Microbiology and ${ }^{2}$ Pharmacology Departments, Faculty of Veterinary Medicine, Beni-Suef \\ University, Beni-Suef, 62511, Egypt.
}

\begin{abstract}
The susceptibility of the most common bacterial pathogens, namely $E$. coli, $P$. mirabilis and $P$ s. aeroginosa which were isolated from egg incubators and yolk sacs of randomly selected one day old Fayoumy chicks to three selected cephalosporins (cephradine, ceftiofur and cefquinome) were studied. The minimum inhibitory concentration (MIC), the minimum bactericidal concentration (MBC) of the tested drugs and the effect of these antibiotics on the body weight gain, mortality and immune response against Newcastle disease (ND) vaccine of the same bread of chicks were also estimated. The tested organisms were sensitive to ceftiofur and cefquinome whereas E.coli and ps. aeroginosa were found to be resistant to cephradine. The results showed that mortalities were higher in control and cephradine treated groups, while it was lower in the ceftiofur and cefquinome treated groups. On the other hand, the lowest mean body weight was recorded in control group $(155.7 \pm 6.55 \mathrm{gm})$ followed by ceftiofur treated group $(162.5 \pm 2.06 \mathrm{gm})$ and the highest mean body weight was recorded in cefquinome treated group $(183.5 \pm 1.66 \mathrm{gm}, \mathrm{p}<0.01)$ at 30 days of age. The study revealed that the tested antibiotics not exert any immune suppressive effect against (ND) vaccine.
\end{abstract}

Colibacillosis refers to localized or systematic infection caused entirely or partially by Escherichia coli (E.coli), including colisepticaemia, coligranuloma, air sac disease, cellulites, swollen head syndrome, peritonitis, salpingitis, osteomylitis, synovitis, omphalitis and yolk sac infection (Barnes and lozano, 1994).

Proteus mirabilis (P. mirabilis) was isolated from dead-in-shell chicken embryos (Orajaka and Mohan, 1985). The organism can penetrate egg shell and survive within the egg (Al-Aboudi et al., 1988). On the other hand, Proteus mirabilis infection mainly causes mortality in young chicks up to 4 weeks of age with suppurative osteomylitis (Venkanagouda et al., 1996).

Pseudomonas organism can cause localized or systemic diseases in young and growing poultry, invade fertile eggs causing death of embryos and newly hatched chicks. Pseudomonas aeroginosa (P. aeroginosa) can be highly virulent causing $100 \%$ mortality in experimentally inoculated chickens Lin et al., (1993), and from 0 to $90 \%$ in broiler chicks (Walker et al., 2002).

Cephradine is $1^{\text {st }}$ generation cephalosporin

* Corresponding author. Tel.: +20 082 2322066;

Fax: +20 0822327982

E-mail address: a.radi@bsu.edu.eg

(Abeer M. Radi) that can be administered orally and used successfully in treating infection of the respiratory tract and soft tissue. The gramnegative aerobic enteric bacilli (E.Coli, $P$. mirabilis, Salmonella spp., and Shigella spp.) were reported to be highly susceptible to the first generation cephalosporins, (Quintilani et al., 1982).

Ceftiofure is a broad spectrum $3^{\text {rd }}$ generation cephalosporrin approved for veterinary use to treat a variety of Gram-negative, Gram-positive bacterial pathogens and anaerobic pathogens including Pasterilla spp., Streptococcus spp., Staphylococcus spp., salmonella spp. and Escherichia coli (Brown et al., 1991; Salmon et al., 1996; Tragesser et al., 2006). Ceftiofur was recomended for the control of P.multocida infection in balady chickens and for control of terminal bacterial infection in one day old broiler chickens (El-Naeneey and lotfy, 2000).

Cefquinome is the $4^{\text {th }}$ generation cephalosporin developed for use in veterinary medicine. It had in vitro and in vivo efficacy against a wide range of gram-negative and grampositive bacterial pathogens, (Limbert et al., 1991; Rohdich et al., 2009).

The present study was carried out to.

Determine the susceptibility of E.coli, P. mirabilis and Ps. aeroginosa isolated from egg incubators and yolk sac of randomly selected day 
old Fayoumy chicks to three selected cephalosporins (cephradine, ceftiofur and cefquinome).

Determine the effect of these antibiotics on chicks' performance.

Studied the effect of the selected antibiotics on chicks' immune response to (ND) vaccine.

\section{Materials and methods}

\section{Drugs.}

Cephradine (velocef) ${ }^{\circledR}$. It was supplied as pure powder for injection from Bristol-Myers Squibb Company, Cairo, Egypt.

Ceftiofur sodium ( Excenel) ${ }^{\circledR}$. It was supplied as seterile powder (1 gram vail) for injection from Pharmacia \& upjohn Company, Cairo, Egypt.

Cefquinome sulphate (Cobactan) ${ }^{\circledR}$. It was obtained as suspention $2.5 \%$ for injection from Intervet International Company Cairo, Egypt.

Samples. A total of 10 samples in the form of cracked shells, dust and fluffs were collected from hatcheries, as well as eighty day old Fayoumy chicks were randomly selected for isolation of bacterial pathogens from their yolk sacs. Fourty day old chicks were randomly selected for collection of blood sampls for application of Heamagglutination Inhibition test for (ND) maternal antibodies .

Media for bacterial isolation and identification. Bacterial fluid and solid media were used for isolation of diferent bacterial pathogens, as each swab was inoculated into tetrathionate broth, tryptone soya broth and MacConkey broth. All fluid media were incubated at $37 . \mathrm{C}$ for 18 hours. A loopfull from each fluid medium was seeded onto the surface of the following solid plating media; salmonella-shigella agar, Tryptone soya agar and MacConkey-bile salt-lactose agar media, followed by aerobic incubation at $37 . \mathrm{C}$ for up to 72 hours. The obtained colonies were identified morphologically and smears were taken stained with Gram's staining technique and identified biochemically according to Collee et al., (1996).

Experimental chicks and grouping. A total number of 1400 one day-old Fayoumy chicks were divided into 4 equal groups; each of 350 chicks. All chicks were floor reared in El-Azab project for poultry production at Fayoumy Governorate. Feeding and lighting programmes were applied according to the catalogue of the project.

In vitro antimicrobial sensetivity test. The bacterial isolates from the egg incubators and egg yolk were examined for sensitivity against three cephalosporines (cephradine, ceftiofur and cefquinome) .

Cephradine, ceftiofur and cefquinome sensitivites were determined using the disc and agar diffussion method as described by Collee $e t$ al., (1996) as follow, A portion of a single bacterial colony was selected and inoculated into $4 \mathrm{ml}$ Muller Hinton broth and incubated at $37 \stackrel{\circ}{\circ} \mathrm{C}$ for 18 hours. After incubation the concentration of the M.O was equal to $1 \times 10^{8} \mathrm{cfu} / \mathrm{ml}$. The culture was flooded onto the surface of welldried Muller Hinton agar plates. The plates were tipped and excess of fluid was removed with a pipette after being sure that entire surface was covered with inoculum. The bacterial culture was allowed to settle for 15 minutes at $37 \circ \mathrm{C}$. The antimicrobial discs of cephradine and ceftiofur (30 ug/disc) and cefquinome (30 ug/well) were asceptically overlaied. The plates were allowed to stand 30 minutes at room temperature, after application of the discs. Then after overnight incubation at $37 \stackrel{\circ}{\circ}$, the plates were examined for inhibition zones. The interpretation of the results were carried out according to Collee et al., (1996).

Minimum inhibitory and bactericidal concentrations [(MIC) and (MBC)]. According to Collee et al., (1996) the drugs were dissolved in sterile distilled water to obtain a concentrations of $10 \mathrm{mg} \mathrm{ml}^{-1}, 1 \mathrm{mg} \mathrm{ml}^{-1}, 0.1 \mathrm{mg}$ $\mathrm{ml}^{-1}$ as stock solutions.

From the $10 \mathrm{mg} \mathrm{ml}^{-1}$ solution $256 \mathrm{ul}, 128 \mathrm{ul}$, $64 \mathrm{ul}, 32 \mathrm{ul}$ were taken and added to tubes containing $20 \mathrm{ml}$ Muller Hinton broth to obtain the following dilutions of antibiotics $(128,64,32$ and $16 \mu \mathrm{g} \mathrm{ml}^{-1}$, respectivelly.

From the $1 \mathrm{mg} \mathrm{m}^{-1}$ solution $160 \mathrm{ul}, 80 \mathrm{ul}$ and $40 \mathrm{ul}$ were taken and added to tubes of Muller Hinton broth to obtain the following dilutions of $\left(8,4,2 \mu \mathrm{g} \mathrm{ml}^{-1}\right)$.

From the $0.1 \mathrm{mg} \mathrm{ml}^{-1}$ tube $200 \mathrm{ul}, 100 \mathrm{ul}, 50$ $\mathrm{ul}$ and $25 \mathrm{ul}$ were added to Muller Hinton broth tubes to obtain dilutions of $(1,0.5,0.25$ and $0.125 \mu \mathrm{g} \mathrm{ml}^{-1}$ ).

Each tube was inoculated with 100 ul of $1 \times 10^{8} \mathrm{cfu} / \mathrm{ml}$ ( prepared by using MecFarland opacity tube) suspention of each of the microorganisms isolated from the egg incubators and chicks.

All tubes were incubated at $37 \stackrel{\circ}{\circ}$ for 24 hours.

At the end of incubation period the tubes were examined visually for turbidity . 
The tubes which has no visible growth indicate the MIC points.

To determine the MBC, a loopfull from the tubes which showing no visible growth were subcultured onto Muller Hinton agar and incubated at $37 . \dot{\mathrm{C}}$ for $24-48$ hours. After incubation of the subculture plates they were examined for growth. The tube containing the lowest concentration of antibiotic that fails to yeiled growth on the subculture plate was regarded as containing $\mathrm{MBC}$ of antibiotic for the tested strain.

Vaccination programme. Chicks groups were received the following viral vaccines.

At 1 day old. Marek's virus vaccine $\mathrm{s} / \mathrm{c}$ in the neck $0.2 \mathrm{ml} /$ chick.

At 2 day old. Infectious bronchitis living attenuated vaccine in drinking water.

At 6 days of age. ND (Hitchner B1) living attenuated vaccine in drinking water.

At 9 days of age. Infectious bursal disease vaccine in drinking water which repeated at 19 days of age.

At 18 days of age. ND (Lasota) vaccine in drinking water which was repeated at 28 days of age.

Experiment NO 1 (The effect of subcutanous injection of the tested drugs on the chicks performance). In this experiment the effect of subcutaneous injection of three doses (at one, 16 and 26 days of age) of cephradine, ceftiofur and cefquinome was studied on the performance ( general health condition, body weight, feed intake, food conversion rate and mortality rate) of 1400 one day old chicks about 27 gm body weight. The chicks were divided into 4 groups each of 350 chicks. The $1^{\text {st }}$ group was injected with cephradine at adose of $50 \mathrm{mg} \mathrm{kg}^{-1}$ b.wt (Oishi et al., 1976), the $2^{\text {nd }}$ group injected ceftiofur (10 mg/kgb.wt.), Aziza et al., (1998), whereas the $3^{\text {rd }}$ group injected cefquinome (2 mg $\mathrm{kg}^{-1}$ b.wt.) Block (1996) and the $4^{\text {th }}$ group was was kept as a non treatrd control. The chicks of each group was weighed at 1, 7, 14, 21, 30 days of age.

Relative growth rate and feed conversion ratio were calculated according to Crampton and Lioyd (1959) as the following:

Relative growth rate $=(\mathrm{w} 2-\mathrm{w} 1) \times 100$

Where:

$$
(w 1+w 2) \div 2
$$

$\mathrm{w} 1=$ body weight at the begining of the period. w2 = body weight at the end of the period.

The feed conversion rate was measured by dividing the amount of food consumed, in a certain period, by the gain in weight at the same period, expressed in the same weight units.

Experiment NO 2 (The effect of the tested drugs on chicks immune response against ND vaccine). Serum samples were collected at the first day by scarifying 40 chicks, then at the $10^{\text {th }}$, $19^{\text {th }}$ and $29^{\text {th }}$ day of age by scarifying 15 chicks from each group and collection of their blood for serum. Collected sera were subjected to for heamagglutination inhibition test ( $\mathrm{HI})$ by the conventional microtitre method according to Calnek (1979).

Statistical analysis. The mean and standerd deviatons were calcluted as described by Snedecor (1969), the F- test was carried out by using INSTAT program.

\section{Results and Discussion}

Bacterial isolates from examined hatchery samples, 6 samples were found to harbour bacterial pathogens from 10 samples, (2 Ecoli, 3 ps. aeroginosa and 1 p. mirabilis isolate) and 22 bacterial pathogens were isolated from the yolk sac of day old chicks, and identified as (9 isolates Ecoli, 8 isolates ps. aeroginosa, 3 isolates $p$. mirabilis and 2 isolates were spore forming aerobic gram- positive bacilli).

These findings nearly coincide with the results obtained by Choudhury et al., (1993) who isolated E.coli from 57 (67.04 \%) of infected yolk sacs on 58 farms. Barnes and Lozano (1994) revealed that egg transmission of pathogenic E.coli is common and can be responsible for high chick mortality. Radwan and Hassan (2004) experimentally induced $68 \%$ embryonic death using p.mirabilis through egg shell.

E. coli and ps. aeroginosa were found to be resistant and $p$.mirabilis was found to be sensitive to cephradine. These finding resemble those obtained by Lacey et al., (1983); Gakuya et al., (2001).

The tested organisms was sensitive to Ceftiofur, this is similar to the result obtained by (El-Naenaey and lotfy 2002) who recorded that in chicks 39 out of 40 tested strains of E.coli were sensitive to ceftiofur, for Ps. aeruginosa the activity percentage of $80 \%$ was recorded to ceftiofur as 4 strains were sensitive from the tested 5 isolates, all tested isolates of proteus species from chicks were completely sensitive. Huang et al., (2009) reported that E.coli, salmonella and $p$. multocida isolates form poultry were sensitive to ceftiofur. On the other hand our study not agrees with the result obtained by (Deshpande et al., 2000) who found 
that the isolates of E.coli which produce extended spectrum $\beta$-lactamase (ESBL) were resistant to ceftiofur. This may be due to the acquired resistance of E.coli. Also (Walker et al., 2002) recorded that antibiotic sensitivity tests showed that $p$. aeruginosa isolates obtained from hatcheries and broiler chicks were resistant to ceftiofur.

The result of our investigations proved that E. coli, P. mirabilis and ps. aeroginosa were sensitive to cefquinome. This finding agreed with that reported by Sheldon et al., (2004) and Rohdich et al., (2009).

MIC and MBC of cephradine for the tested E. coli, P. mirabilis and Ps. aeroginosa were 32,128 and $>128 \mu \mathrm{g} \mathrm{ml}^{-1}$ and $64,128,>128 \mu \mathrm{g}$ $\mathrm{ml}^{-1}$., respectively (Table 1 ).

The MIC and MBC of ceftiofur for E. coli, $P$. mirabilis and ps. aeroginosa investigated in this study were $0.5,16,>128 \mu \mathrm{g} \mathrm{m}^{-1}$ and $0.5,16$ and $>128 \mu \mathrm{g} \mathrm{ml}^{-1}$ respectively. These results similar to that recorded by (Deshpande et al., 2000 ), the MIC of ceftiofur and cefquinome for E.coli were $\left(0.06-2\right.$ and $\leq\left(\begin{array}{llll}0.03 & -1 \mu \mathrm{g} \mathrm{ml}^{-1}\end{array}\right)$, respectively but resistant strains of E.coli exert MIC $>32 \mu \mathrm{g} \mathrm{ml}^{-1}$ for both drugs. Meyer et al., (2008) recorded that the MIC for E.coli in foals was $\leq(0.5-1 \mu \mathrm{g} / \mathrm{ml})$.

This study revealed that MBCs for ceftiofur is similar to its MICs against most tested strains strongly suggest that ceftiofur exerts bactericidal effect. This result confirmed the findings of Franklin (1992) and Klein et al., (1996); they reported that ceftiofur sodium exerts bactericidal effect on tested isolates at concentration equal to or at most one doubling dilution above MIC.

The MIC and MBC of cefquinome for the tested bacteria E. coli, P. mirabilis and Ps. aeroginosa investigated in this study were $0.5,1$, $16 \mu \mathrm{g} \mathrm{ml}^{-1}$ and 1,16 and $>128 \mu \mathrm{g} \mathrm{m}{ }^{-1}$, respectively. This finding similar to that obtained by Limbert et al., (1991) who recorded that the MIC for E. Coli $\left(<0.006-0.781 \mu \mathrm{g} \mathrm{ml}^{-1}\right), P$. mirabilis $\left(0.024-0.39 \mu \mathrm{g} \mathrm{ml}^{-1}\right)$, ps. aeroginosa $\left(0.391-50 \mu \mathrm{g} \mathrm{ml}^{-1}\right)$. Also the MIC for E Coli and P. mirabilis was less than or equal to $0.5 \mu \mathrm{g} \mathrm{ml}^{-1}$, while MIC for ps. aeroginosa $8 \mathrm{ug} \mathrm{ml}^{-1}$ and MBC for most species except Enterobacter were within a dilution of MIC, Chin et al., (1992); Murphy et al., (1994). Cefquinome had MIC value for E.coli $<0.06 \mu \mathrm{g} / \mathrm{ml}$ in cattle by Sheldon et al., (2004) and Thomas et al., (2006).

Performance of different groups of chicks under study. As shown in Tables (2 and 3), mortalities were higher in control (53 chicks) and cephradine treated group (33) and lower in the other two groups (21 and 20) in ceftiofur and cefquinome treated groups, respectively). Regarding total feed intake, the control nontreated group showed the highest quantity of feed intake (632.78 gm/chick in 30 days) followed by cefquinome treated group (593.21 $\mathrm{gm} / \mathrm{chick}$ ). On the other hand, the lowest mean body weight was recorded in control group (155.7 gm \pm 6.55 ) followed by ceftiofur treated group (162.5gm \pm 2.06$)$ and the highest mean body weight was recorded in cefquinome treated group (183.5 gm \pm 1.66$),(p<0.01)$ in 30 days. Mean weight gain was highest in cefquinome treated group (156.5) and lowest in control group (128.7).The excellent feed conversion rate was obtained in the third cefquinome treated group (3.79) followed by ceftiofur treated group (4.09) mean while it was (4.18) and (4.92) in cephradine and control groups, respectively. Relative growth rate was highest (148.69) in cefquinome treated group and lowest (140.88) in control treated group (Table 3).

Egg-born diseases are transmitted from the infected dam to newly hatched offspring by means of fertile eggs. Some disease agents are carried inside the shell as a result of shedding into the egg piror to the addition of shell membrane. Others are carried out on the shell or penetrate from the shell surface through pors after the egg is laied (Radwan and Hassan, 2004). The ability of ceftiofur and cefquinome to reduce mortality rate were detected in this study and the efficacy of both drug were also evident by improved mean body weight gain, feed intake and feed conversion. This previous data is supported by Alxander, (1985) who reported that after the lapse of the acute phase of the infection the drugs improve weight gain in consequence of an increased feed intake and increased absorption of nutrients.

The used chicks had ND maternal antibodies titers of $\log _{2} 6$. Serum samples were collected from all groups at 10, 19 and 29 days of age and the mean antibody titer of each group was showed in Table (4).

It was clear that ceftiofur treated group recorded non significant decrease antibody titer against ND vaccine, mean while cefquinome treated group recorded non significant increase antibody titer.

Conclusion. From the previous study we could concluded that:

Cephradine could be used for treatment of potential infections with Proteus mirabilis. 
Table (1): Minimum inhibitory and bactericidal concentrations $\{(\mathrm{MIC})$ and (MBC) $\}$ of the tested drugs.

\begin{tabular}{lcccccc}
\hline \multirow{2}{*}{$\begin{array}{l}\text { Tested } \\
\text { M.Os }\end{array}$} & \multicolumn{2}{c}{ Cephradine } & \multicolumn{2}{c}{ Ceftiofur } & \multicolumn{2}{c}{ Cefquinome } \\
\cline { 2 - 7 } & $\begin{array}{l}\mathrm{MIC} \\
\left(\mu \mathrm{g} \mathrm{ml}^{-1}\right)\end{array}$ & $\begin{array}{l}\mathrm{MBC} \\
\left(\mu \mathrm{g} \mathrm{ml}^{-1}\right)\end{array}$ & $\begin{array}{l}\mathrm{MIC} \\
\left(\mu \mathrm{g} \mathrm{ml}^{-1}\right)\end{array}$ & $\begin{array}{l}\mathrm{MBC} \\
\left(\mu \mathrm{g} \mathrm{ml}^{-1}\right)\end{array}$ & $\begin{array}{l}\mathrm{MIC} \\
\left(\mu \mathrm{g} \mathrm{ml}^{-1}\right)\end{array}$ & $\begin{array}{l}\mathrm{MBC} \\
\left.(\mu \mathrm{g} \mathrm{ml})^{-1}\right)\end{array}$ \\
\hline E. coli (1 isolates) & 32 & 64 & 0.5 & 0.5 & 0.25 & 1 \\
$P$. mirabilis $(1$ isolates) & 128 & 128 & 16 & 16 & 1 & 16 \\
Ps.aeroginosa $(1$ isolates) & $>128$ & $>128$ & $>128$ & $>128$ & 16 & $>128$ \\
\hline
\end{tabular}

Table (2): Effect of cephradine, ceftiofur and cefquinome on mortalities and performance in chicks.

\begin{tabular}{|c|c|c|c|c|c|c|}
\hline $\begin{array}{c}\text { Group } \\
\text { (350 chicks/group) }\end{array}$ & $\begin{array}{l}\text { Mortality } \\
\text { per number } \\
\text { (350 chicks) }\end{array}$ & $\begin{array}{l}\text { Feed } \\
\text { intake } \\
\text { (gm) } \\
\text { per chick }\end{array}$ & $\begin{array}{l}\text { Mean body weight } \\
\text { (gm) per chick } \\
\mathrm{n}=80 \text { chicks }\end{array}$ & $\begin{array}{l}\text { Mean weight } \\
\text { gain (gm) per } \\
\text { week }\end{array}$ & $\begin{array}{l}\text { Feed } \\
\text { conversion } \\
\text { rate } \\
\text { (week) }\end{array}$ & $\begin{array}{l}\text { Relative } \\
\text { growth } \\
\text { rate }\end{array}$ \\
\hline \multicolumn{7}{|l|}{7 days of age } \\
\hline $1^{\text {st }}$ group (Cephradine) & 8 chicks & 87.7 & $57.3 \pm 0.47$ & 30.25 & 2.89 & 71.8 \\
\hline $2^{\text {nd }}$ group ( Ceftiofur) & 9 & 87.98 & $54.75 \pm 1.49$ & 27 & 3.25 & 65.06 \\
\hline $3^{\text {rd }}$ group (Cefquinome ) & 6 & 86.48 & $58.5 \pm 1.5$ & 31.5 & 2.74 & 73.68 \\
\hline $4^{\text {th }}$ group (Control group) & 27 & 91.33 & $57.5 \pm 0.645$ & 30.3 & 3.014 & 71.7 \\
\hline \multicolumn{7}{|l|}{14 days of age } \\
\hline $1^{\text {st }}$ group (Cephradine) & 13 & 149.5 & $94 \pm 2.81$ & 36.8 & 4.06 & 48.6 \\
\hline $2^{\text {nd }}$ group ( Ceftiofur) & 6 & 158.9 & $92.4 \pm 1.43$ & 36.4 & 4.4 & 49.06 \\
\hline $3^{\text {rd }}$ group (Cefquinome ) & 10 & 156.86 & $100.6 \pm 1.79$ & 42.1 & 3.72 & 52.9 \\
\hline $4^{\text {th }}$ group (Control group) & 13 & 148.4 & $92.75 \pm 0.36$ & 35.25 & 4.2 & 46.93 \\
\hline \multicolumn{7}{|l|}{21 days of age } \\
\hline $1^{\text {st }}$ group (Cephradine) & 2 & 179.1 & $130.4 \pm 1.46^{*}$ & 36.2 & 4.95 & 32.3 \\
\hline $2^{\text {nd }}$ group ( Ceftiofur) & 1 & 160.4 & $132.1 \pm 2.27 * *$ & 39.7 & 4.04 & 35.3 \\
\hline $3^{\text {rd }}$ group (Cefquinome ) & 2 & 166.1 & $135.2 \pm 0.71 * * *$ & 42.1 & 3.94 & 34.6 \\
\hline $4^{\text {th }}$ group (Control group) & 3 & 206.7 & $123.6 \pm 1.03$ & 31.6 & 6.54 & 24.73 \\
\hline \multicolumn{7}{|l|}{30 days of age } \\
\hline $1^{\text {st }}$ group (Cephradine) & 10 & 152.06 & $163 \pm 3.93$ & 32.6 & 4.66 & 22.3 \\
\hline $2^{\text {nd }}$ group ( Ceftiofur) & 5 & 146.96 & $162.5 \pm 2.06$ & 30.4 & 4.83 & 20.6 \\
\hline $3^{\text {rd }}$ group (Cefquinome ) & 2 & 183.77 & $183.5 \pm 1.66^{* *}$ & 40.8 & 4.51 & 25 \\
\hline $4^{\text {th }}$ group (Control group) & 10 & 186.35 & $155.7 \pm 6.55$ & 32.1 & 5.8 & 22.1 \\
\hline
\end{tabular}

Table (3): Comparison between different groups of chicks demonstrating important items of performance.

\begin{tabular}{|c|c|c|c|c|}
\hline \multirow[b]{2}{*}{ Performance } & \multicolumn{4}{|c|}{ Group } \\
\hline & $\begin{array}{c}1^{\text {st }} \text { group } \\
\text { (Cephradine) }\end{array}$ & $\begin{array}{l}2^{\text {nd }} \text { group } \\
\text { (Ceftiofur) }\end{array}$ & $\begin{array}{c}3^{\text {rd }} \text { group } \\
\text { (Cefquinome) }\end{array}$ & $\begin{array}{c}4^{\text {th }} \text { group } \\
\text { (control non } \\
\text { treated group) }\end{array}$ \\
\hline Total mortalities & 33 & 21 & 20 & 53 \\
\hline $\begin{array}{l}\text { Total average Feed intake }(\mathrm{gm}) / \text { chick } \\
\text { in } \mathbf{3 0} \text { days }\end{array}$ & 568.36 & 554.24 & 593.21 & 632.78 \\
\hline Mean body weight (gm) at 30 days of age & $163 \pm 3.93$ & $162.5 \pm 2.06$ & $183.5 \pm 1.66^{* *}$ & $155.7 \pm 6.55$ \\
\hline Mean body gain in 30 days & 136 & 135.5 & 156.5 & 128.7 \\
\hline Food conversion rate at 30 days of age & 4.18 & 4.09 & 3.79 & 4.92 \\
\hline Relative growth rate at 30 days of age & 143.16 & 143 & 148.69 & 128.7 \\
\hline
\end{tabular}

$* * \mathrm{P}<0.01$ 


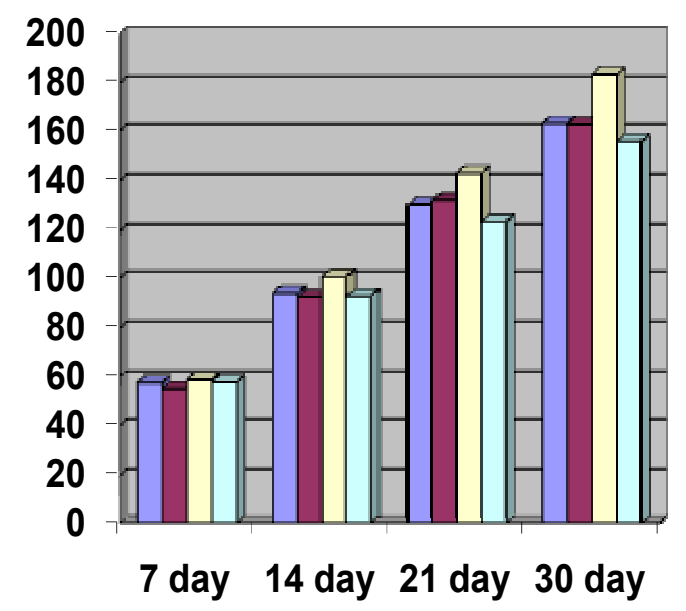

\begin{tabular}{|l|}
$\square$ cephradine group \\
$\square$ ceftiofur group \\
$\square$ cefquinome group \\
$\square$ control group
\end{tabular}

Fig. (1): Mean body weight in the different chicks groups.

Table (4): Effect of cephradine, ceftiofur and cefquinome on ND Mean HI $\log _{2}$ of antibody titers.

\begin{tabular}{lcccc}
\hline \multirow{2}{*}{ Age per days } & \multicolumn{4}{c}{ Group } \\
\cline { 2 - 5 } & Cephradine group & Ceftiofur group & $\begin{array}{c}\text { Cefquinome } \\
\text { group }\end{array}$ & $\begin{array}{c}\text { Control non } \\
\text { treated group }\end{array}$ \\
\hline One day age & 6 & 6 & 6 & 6 \\
At 10 days of age & 11 & 11 & $9.85 \pm 0.40$ & $10 \pm 0.45$ \\
At 19 days of age & $9.57 \pm 0.68$ & $6.714 \pm 0.61$ & $9 \pm 0.44$ & $8.16 \pm 0.6$ \\
At 29 days of age & $8.33 \pm 0.45$ & $5.7 \pm 0.39$ & $9.1 \pm 0.655$ & $7.33 \pm 0.65$ \\
\hline
\end{tabular}

Non significant variation $(\mathrm{p}>0.05)$.

Cefquinome and ceftiofur could be used for treatment of potential infections with Esherchia coli, Proteus mirabilis and pseudomonas aeroginosa microorganisms.

Mortalities were lower in chicks treated by ceftiofur and cefquinome while the highest mean body weight was recorded in cefquinome treated chicks.

Cephradine, ceftiofur and cefquinome did not exert any immunosuppressive effect against Newcastle disease vaccine thus they could be used safely before vaccination without adverse effect on the immune response of chickens.

\section{References}

Al-Aboudi, A. R.; Shinawa, I. M.; Hassen, A. A. and AlSanjary, R. B. (1988): Penetration rate of proteus organisms throuogh egg shell membranes at different temperature. Iraqi J..Vet. .Sci., 1: 1-8.

Alexander, F. (1985): An introduction of vet. pharm. $4^{\text {th }}$ Ed. Longman (London and NewYork).

Aziza, M. M. Amer; Eisha, M. M. Fahim and Rawia, K. Ibrahim (1998): Effect of aflatoxicosis on the kinetic behaviour of ceftiofur in chickens. Res. Vet. Sci., 65(2): 115-118.

Barnes, H. J. and Lozano, F. (1994): Colibacilloses in poultry. In Pfizer veterinary practicum, Pfizer Animal Health. Leeys summit MO. 45 pp.
Block, C. Von (1996): Pharmacokinetics of the cephalosporin antibiotic cefquinome in sows at different stages of the reproductive cycle. InauguralDissertation,Tierarztliche Fakultat, Ludwig-Maximilian Universitat, Munchen, Germany.

Brown, S. A.; Yancey, R. J. and Stef, J. (1991): Ceftiofur sodium: Antimicrobial activity of parent ceftiofur and metabolites. Acta Veterinaria Scandinavica; 87:95-97.

Calnek, B.W. (1979): Haemagglutination-inhibation antibodies against an adenovirus (virus127) in white pekin ducks in the United States. Avian Dis., 22(4):798-801.

Chin, N.; Gu, J.; Fang, W. and Neu, H. (1992): Invitro activity of cefquinome, a new cephalosporin, compare with other cephalosorin antibiotics. Diagn. Microbial Infect. Dis., 15(4):331-337.

Choudhury, B.; Chanda, A.; Dasgupta, P.; Dutta, R.K.; Lila-saha; Sanatan-Bhuin; saha, L. and Bhuin, S.(1993): Studies on yolk sac infection in poultry, antibiogram of isolates and correlation between in-vitro and in vivo drug action . Ind. J. Anim. Hlth., 32(1):21-23.

Collee, C. J.; Barrie, P. M.; Andrew, G. F. and Anthory S. (1996): Cited in Mackie \& Mccartney Practical medical microbiology. $4^{\text {th }}$ ed. 151-178. Newyork EclinBurgh London.

Crampton, E.W. and Lioyd, L.E. (1959): Fundmentals of nutrition. W.H. Freeman and company.Sanfranciso and London.

Deshpande, L.; Pfaller, M. A. and Jones, R.N. (2000): In vitro activity of ceftiofure tested against clinical isolates of Escherichia coli and Klebsiella pneumoniae including 
extended spectrum-beta lactamase producing strains. Int. J Antimicrob. Agents, 15(4): 271-275.

El-Naeneey, E.Y. and Lotfy, O. O. (2002): Experimental and field trials to evaluate the antibacterial action of ceftiofur sodium (Excenel) in chickens. Vet. Med. J., Giza. 48(2): 207-216.

Franklin, A. (1992): The in-vitro bactericidal activity of Danofloxacin and ceftiofure against respiratory pathogens in cattle. Proceedings $17^{\text {th }}$ world Buiatrics Congress, 3:214217.

Gakuya, F. M; Kyule, M. N; Gathura, P. B. and Kariuki, S. (2001): Antimicrobial resistance of bacterial organisms isolated from rats. East. Afr. Med. J., 78(12):646-649.

Huang, T. M.; Lin, T. L. and Wu, C.C. (2009): Antimicrobial susceptibility and resistance of Escherichia coli, Salmonella spp. and Pasteurella multocida isolates. Avian Dis., 53(1):89-93.

Klein, L. k; Yancey, R. J.; Case, C. A. and Salmon, S. A. (1996): Minimum inhibitory concentration of selected antimicrobial agent against bacteria isolated from1-14 day old broiler chicks. J. Vet. Diag. Invest., 8 (4):494-495.

Lacey, R. W.; Gillian, L. H.; Vickil, l.; Luxton, D. E. A. and Trotter, I. S. (1983): Double-blind study to compare the selection of antibiotic resistance by Amoxycillin or Cephradine in the commensal flora. The lancet, 322(8349): 529-532.

Limbert, M.; Isert, D.; Klesel, N.; Markus, A.; Seeger, K.; Seibert, G. and Schrin, E. (1991): Antibacterial activities in vitro and in vivo and pharmacokinetic of cefquinome (HR111V), anew broad-spectrum cephalosporin. Antimicrob. Agents Chemoth., 35(1):1419.

Lin, M.Y.; Cheng, M. C.; Huang, K. J. and Tsai, W. C. (1993): Classification, pathogenicity, and drug susceptibility of hemolytic Gram-negative bacteria isolated from sick or dead chickens. Avian Dis., 37:6-9.

Murphy, S. P.; Erwin, M. E. and Jones, R. N. (1994): Cefquinome (HR11V) in vitro evaluation of a broadspectrum cephalosporin indicated for infections in animals. Diagn. Microbial. Infect. Dis., 20:49-55.

Oishi, M.; Nishizuka, K.; Motoyama, M.; Ogawa, T. and Tanaka, M. (1976): Ophthalmic application of intravenous cephradine. Jpn. J. Antibiot., 29(11):958-962.

Orajaka, L. J. E. and Mohan, k. (1985): Aerobic bacterial flora from dead-in shell chicken embryo from Nigeria. Avian Dis., 29:583-589.

Quintilani, R.; French, M. and Nightingale, G. M. (1982): First and second generation cephalosporins. Antimicrobial Therapy. Med. Clin. North Am.; 66: 183197.

Radwan, I. A. and Hassan, W. H .(2004): Comparative exclusion of proteus mirabilis causing cloacal prolapse and embryonic chicken deaths. Beni-Suef Vet. Med. J. XIV. (1):29-37.

Rohdich, N.; Zschiesche, E.; Heckeroth, A.; Wilhelm, C.; Leendertse, I. and Thomas, E. (2009): Treatment of septicaemia and severe bacteria infections in foals with a new cefquinome formulation: a field study. DTW., 116 (9): 316-20.

Salmon, S. A.; Wattsm, J. L. and Yancey, R. J. (1996): In vitro activity of ceftiofur and its primary metabolite desfuroylceftiofur, against organisms of veterinary importance. J. Vet. Diag. Inv., 8:322-336.

Sheldon, I. M.; Bushnell, M.; Montgomery, J. and Rycroft, A. N. (2004): Minimum inhibitory concentrations of some antimicrobial drugs against bacteria causing uterine infections in cattle. Vet. Rec., 25:155(13):383-387.

Snedecor, G.W. (1969): Statistical methods. $4^{\text {th }}$ Ed. The Lowa state Univ. press, Ames., Lowa, USA., 91.

Thomas, E.; Thomas, V. and Wilhelm, C. (2006): Antibacterial activity of cefquinome against equine bacterial pathogens. Vet. Microbiol., 115(1-3):140-147.

Tragesser, L. A.; Wittum, T. E.; Funk, J. A.; Winokur, P. L. and Rajala Schultz, P. J. (2006): Association between ceftiofur use and isolation of Escherichia coli with reduced susceptibility to ceftriaxone from fecal samples of dairy cows. Amer. J. Vet. Res., 67:1696-1700.

Venkanagouda; Krishnappa, G. and Upadhye, A.S. (1996): Bacterial etiology of early chick mortality. Ind. Vet. J., 73: (3) 253-256.

Walker, S. E.; Sander, J. E.; Cline, J. L. and Helton, J. S. (2002): Characterization of Pseudomonas aeruginosa isolates associated with mortality in broiler chicks. Avian Dis., 46(4):1045-1050.

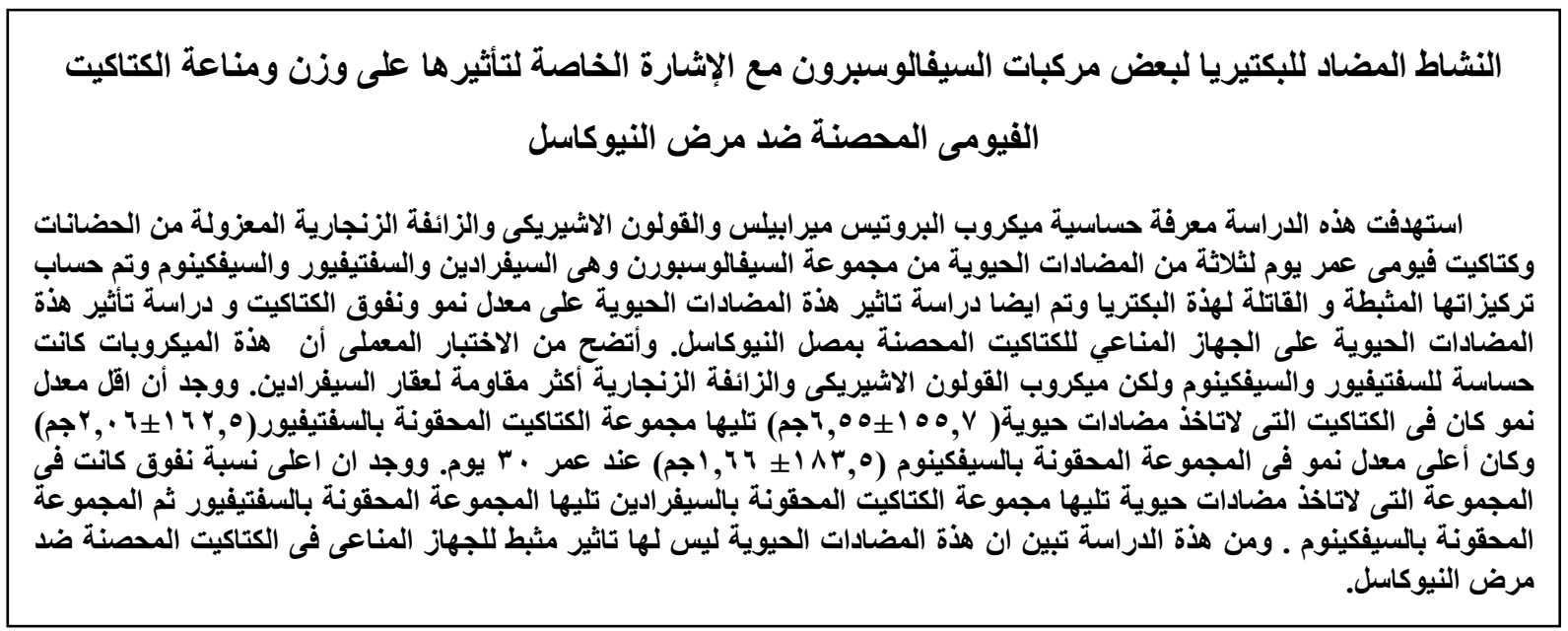

